\title{
Eradicating Helicobacter pylori infection lowers gastrin mediated acid secretion by two thirds in patients with duodenal ulcer
}

\author{
E El-Omar, I Penman, C A Dorrian, J E S Ardill, K E L McColl
}

Abstract

Helicobacter pylori (H pylori) raises serum gastrin but it is unclear whether this stimulates increased acid secretion. Gastrin mediated acid secretion and plasma gastrin after the intravenous infusion of gastrin releasing peptide was studied in nine $\boldsymbol{H}$ pylori negative and nine $H$ pylori positive healthy volunteers, and in 11 duodenal ulcer patients. Nine of the last group were re-examined one month after eradication of $\boldsymbol{H}$ pylori. The median acid output (mmol/h) to gastrin releasing peptide $(40 \mathrm{pmol} / \mathrm{kg} / \mathrm{h})$ in the $H$ pylori positive healthy volunteers was $15 \cdot 1$ (range $3 \cdot 3-38 \cdot 3$ ), which was three times that of the $H$ pylori negative healthy volunteers (median $=5.5$, range $1.0-9.0)(p<0.02)$. The median acid output in the duodenal ulcer patients with $\boldsymbol{H}$ pylori was 37 (range 8.5-57), which was > six times that of the $H$ pylori negative healthy volunteers. Eradication of $\boldsymbol{H}$ pylori in the duodenal ulcer patients lowered their acid secretion by a median of $66 \%$ (range $30 \%-80 \%)(p<0.01)$ and to values equivalent to the $H$ pylori positive healthy volunteers. The pepsin output in response to gastrin releasing peptide followed the same pattern as the acid output. The median plasma gastrin concentrations during gastrin releasing peptide were similar in the $H$ pylori positive duodenal ulcer patients (150 ng/l, range 95-400) and $H$ pylori positive healthy volunteers $(129 \mathrm{ng} / \mathrm{l}$, range $23-420)$ and both were appreciably higher than $H$ pylori negative healthy volunteers $(60 \mathrm{ng} / \mathrm{l}$, range 28-135) ( $<<0.005$ for each). Eradication of $H$ pylori lowered the plasma gastrin in the duodenal ulcer patients to values equivalent to the $H$ pylori negative healthy volunteers. These findings show a threefold increase in acid secretion in $H$ pylori positive healthy volunteers that is explained by $H$ pylori induced hypergastrinaemia and a sixfold increase in acid secretion in the duodenal ulcer patients that is explained by the combination of $H$ pylori induced hypergastrinaemia and an exaggerated acid response to stimulation by gastrin. Eradicating $\boldsymbol{H}$ pylori lowers gastrin mediated acid secretion by $66 \%$ in duodenal ulcer patients as a result of the resolution of the hypergastrinaemia. Increased gastrin mediated acid secretion seems to be the key factor in the pathophysiology of duodenal ulceration and explains the role of $H$ pylori infection in the disorder.

(Gut 1993; 34: 1060-1065)

Helicobacter pylori ( $H$ pylori) infection is now recognised to be the main acquired factor in the pathogenesis of duodenal ulcer disease. It is present in $>95 \%$ of duodenal ulcer patients and numerous studies have shown that eradicating the infection dramatically lowers the ulcer relapse rate. ${ }^{1-4}$ The mechanism by which this infection, which predominantly affects the antral mucosa, predisposes to ulceration of the duodenum is unknown. Also, the reason why only a small proportion of subjects with this common infection develop duodenal ulceration is unclear.

We and others have shown that both duodenal ulcer patients and healthy volunteers with $H$ pylori have increased basal and meal stimulated gastrin concentrations that fall after eradication of the infection. ${ }^{5-9}$ Though gastrin is recognised to be the main mediator of meal stimulated acid secretion, ${ }^{10}$ the effect of $H$ pylori on acid secretion remains unclear. A major reason for this is the technical difficulty of reliably determining acid output in response to a meal. To overcome this problem we have measured gastrin mediated acid secretion after the intravenous infusion of gastrin releasing peptide. This stimulates the release of endogenous gastrin, which in turn stimulates acid secretion, and thus makes it possible to measure accurately the combined functional response of the antrum and body of the stomach. Gastrin releasing peptide like peptides also stimulate the release of cholecystokinin ${ }^{11}$ and somatostatin ${ }^{12}$ as well as other gastric inhibitory hormones" and in this way simulate the response to eating.

To elucidate the effect of $H$ pylori on gastric function, we have examined basal and gastrin mediated acid secretion in healthy volunteers with and without $H$ pylori and also in duodenal ulcer patients before and after eradicating the infection.

\section{Patients and methods}

Eleven $H$ pylori positive patients (eight men) with chronic duodenal ulcer disease proved by endoscopy, nine $H$ pylori positive healthy volunteers (seven men), and nine $H$ pylori negative healthy volunteers (six men) were studied. The three groups were matched for age and body weight. There were eight smokers in the duodenal ulcer group and three in each of the other two groups. Duodenal ulcer patients were asked to stop any antisecretory treatment two weeks before the secretory studies. None of the healthy volunteers were taking any drug and none reported major gastrointestinal symptoms. $H$ pylori infection was confirmed in the duodenal ulcer patients by microscopic examination of antral biopsy rapid urease test (CLO test) on antral biopsy, and by ${ }^{1+} \mathrm{C}$ urea breath test. In 

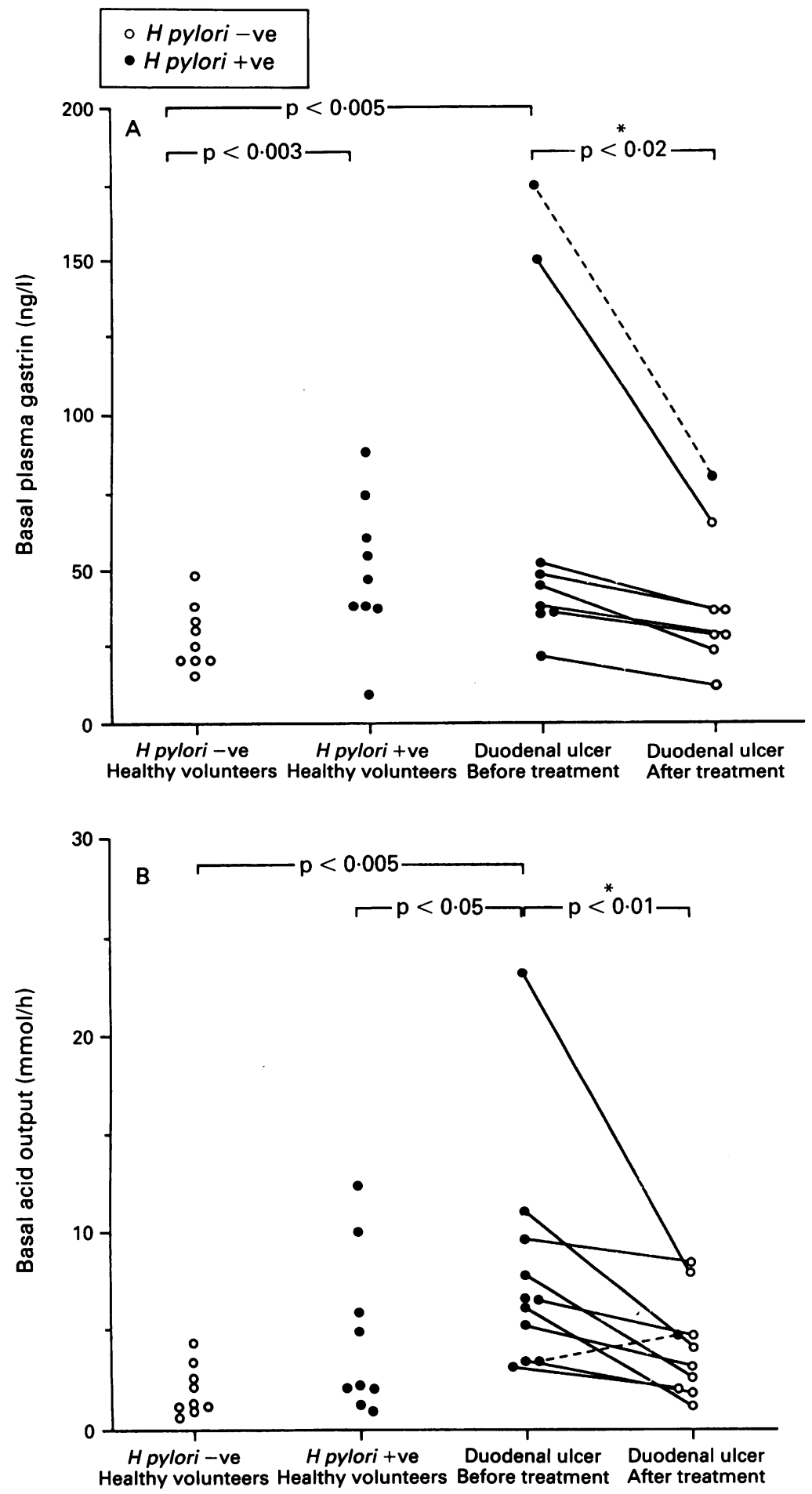

Figure 1: Basal plasma gastrin concentrations $(A)$ and basal acid output $(B)$ in healthy volunteers with and without $\mathrm{H}$ pylori, and in duodenal ulcer patients before and after $\mathrm{H}$ pylori eradication treatment. The before and after treatment values in the patient in whom the infection was not eradicated are joined by broken line. Statistics applies only to the patients in whom the infection was eradicated. that applies suction for 20 seconds in each 32 second cycle. Three 15 minute collections were obtained basally and at each of the following rates of intravenous infusion of gastrin releasing peptide: $10,40,100$, and $200 \mathrm{pmol} / \mathrm{kg} / \mathrm{hr}$. Blood samples were collected every 15 minutes for gastrin determination and the plasma stored at $-20^{\circ} \mathrm{C}$. The secretory studies were all performed with the investigator blind to the subjects' $H$ pylori state.

Gastrin releasing peptide was purchased from Cambridge Research Biochemicals (Cheshire, England) in $0.5 \mathrm{mg}$ aliquots. Each aliquot was made up into a stock solution by dissolving in sterile water. $0 \cdot 1 \mathrm{ml}$ of $50 \%$ acetic acid solution was added to stablilise the solution. Aliquots were stored at $-80^{\circ} \mathrm{C}$. For each study the aliquot was further diluted in $0.9 \% \mathrm{NaCl}$ solution.

The volume and $\mathrm{pH}$ of each gastric juice collection was recorded and its hydrogen ion concentration measured by titration with $0.1 \mathrm{~N}$ $\mathrm{NaOH}$ to $\mathrm{pH} 7$ using an autotritrator (Radiometer ETS 822). Gastric juice aliquots for pepsin measurement were centrifuged at $4^{\circ} \mathrm{C}$. One $\mathrm{ml}$ of each aliquot was added to $0.3 \mathrm{ml}$ of a Glycerol/ $\mathrm{HCl}(10 \mathrm{mmol})$ solution $50 / 50 \mathrm{vol} / \mathrm{vol})$. Samples were stored at $-80^{\circ} \mathrm{C}$ before determination of pepsin activity by the method of Gray and Billings. ${ }^{13}$

Basal acid output was calculated by taking the mean of all three 15 minute samples before gastrin releasing peptide infusion. Acid and pepsin outputs for each gastrin releasing peptide infusion rate were calculated by taking the mean of the second and third 15 minute collections. Pepsin measurements were not performed in two of 10 duodenal ulcer patients after treatment.

Gastrin was measured by radioimmunoassay with antiserum $\mathrm{R} 98^{14}$ that has a sensitivity of $5 \mathrm{ng} / \mathrm{l}$. The basal gastrin value for each subject was measured by taking the mean of the three samples obtained before the start of gastrin releasing peptide infusion. The gastrin value at each infusion rate of gastrin releasing peptide was measured by taking the mean of the two values at 30 and 45 minutes of each infusion. To ensure accuracy, gastrin measurements were performed in the same assay batch. For this reason, gastrin results are not available in two of 11 duodenal ulcer patients before treatment and two of 10 duodenal ulcer patients after treatment who entered the study later.

\section{ERADICATION OF H PYLORI}

After the above secretory studies, 10 duodenal ulcer patients were treated with tripotassium dicitratobismuthate $120 \mathrm{mg}$ three times daily, metronidazole $400 \mathrm{mg}$ three times daily, and amoxycillin $500 \mathrm{mg}$ three times daily for three weeks. One month after completion of this treatment their ${ }^{14} \mathrm{C}$-urea breath test was repeated to assess the $H$ pylori state. Their secretory studies were also repeated at this point.

All subjects reported at 0900 after a 12 hour fast. An orogastric tube (Anderson Inc, New York) was swallowed and its position in the dependent part of the stomach checked by the water recovery test. After emptying the stomach, intermittent suction was applied using an intermittent suction unit (Ohmeda, Columbia, USA)

\section{STATISTICS}

Statistical analysis of unpaired data was performed using the Mann-Whitney $U$ test and of paired data using the Wilcoxin test. A p value of 

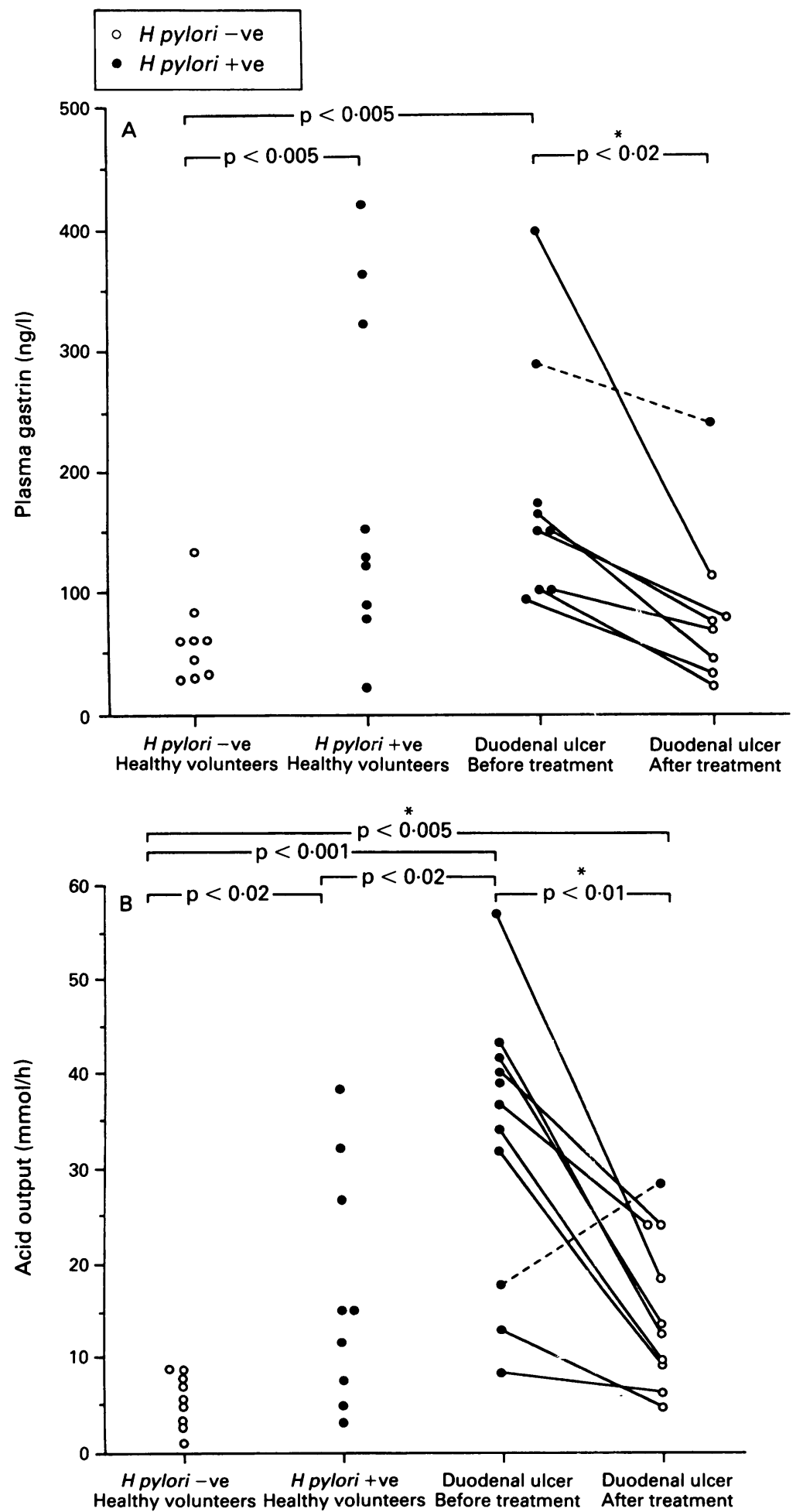

Figure 2: Plasma gastrin concentrations $(A)$ and acid output $(B)$ during intravenous infusion of gastrin releasing peptide $(40 \mathrm{pmol} / \mathrm{kg} / \mathrm{h})$. The before and after treatment values in the patient in whom the infection was not eradicated are joined by broken line. ${ }^{\star}$ Statistics applies only to the patients eradicated of $\mathrm{H}$ pylori.
BASAL GASTRIN

The medium basal gastrin (ng/l) was increased by a similar extent in the $H$ pylori positive healthy volunteers (45, range $10-88$ ) and $H$ pylori positive duodenal ulcer patients (47, range $22-$ 175) compared with the $H$ pylori negative healthy controls $(25$, range $15-48)(\mathrm{p}<0.005$ for both) (Fig 1A). After eradication of $H$ pylori the median serum gastrin in the duodenal ulcer patients fell to 28 (range 12-65) $(\mathrm{p}<0.02 v$ before eradication), which was similar to the value in the $H$ pylori negative healthy volunteers.

BASAL ACID SECRETION

The median basal acid output ( $\mathrm{mmol} / \mathrm{h}$ ) was similar in the $H$ pylori negative $(1 \cdot 3$, range $0 \cdot 7-4 \cdot 6)$ and positive $(2 \cdot 2$, range $1 \cdot 0-13 \cdot 3)$ healthy volunteers (Fig 1B). It was increased in the $H$ pylori positive duodenal ulcer patients (6.6, range $3 \cdot 1-23 \cdot 2)$, however, compared with both the $H$ pylori negative healthy volunteers $(\mathrm{p}<0.005)$ and $H$ pylori positive healthy volunteers $(\mathrm{p}<0.05)$. Eradication of $H$ pylori lowered the median basal acid output in the nine duodenal ulcer patients to 3.6 (range $1.2-8.4)(\mathrm{p}<0.01 v$ before eradication), representing a median reduction of $50 \%(20 \%-80 \%)$. The basal acid output in the one duodenal ulcer subject in whom $H$ pylori infection was not eradicated was similar before $(3 \cdot 7)$ and after $(4 \cdot 8)$ the triple treatment.

\section{GASTRIN RESPONSE TO GASTRIN RELEASING PEPTIDE}

At the gastrin releasing peptide infusion rate of $40 \mathrm{pmol} / \mathrm{kg} / \mathrm{h}$ the median plasma gastrin concentration (ng/l) was increased to a similar value in the $H$ pylori positive healthy volunteers (129, range 23-420) and $H$ pylori positive duodenal ulcer patients (150, range 94-400) and each was higher than that of the $H$ pylori negative healthy volunteers (60, range 28-135) $(\mathrm{p}<0.005$ for each) (Fig 2A). After eradication of $H$ pylori the median gastrin concentration in response to gastrin releasing peptide $40 \mathrm{pmol} / \mathrm{kg} / \mathrm{h}$ in the nine duodenal ulcer patients fell to 68 (range 23115) $(\mathrm{p}<0.02 v$ before eradication), which was similar to the value in the $H$ pylori negative healthy volunteers.

Though the gastrin concentration increased with increasing gastrin releasing peptide infusion rates, the four groups of subjects showed the same pattern of response at each infusion rate (Fig $3 \mathrm{~A})$. The statistical differences between the groups were the same at each infusion rate as that seen at $40 \mathrm{pmol} / \mathrm{kg} / \mathrm{h}$. We chose to present the results of the individual data points for the $40 \mathrm{pmol} / \mathrm{kg} / \mathrm{h}$ gastrin releasing peptide rate as the gastrin concentrations stimulated by this are closest to those seen after a meal.

s taken as significant. The st approved by the Western Infirmary Ethical Committee.

\section{Results}

The repeat ${ }^{14} \mathrm{C}$-urea breath test at one month after completion of the triple anti- $H$ pylori treatment showed that the infection had been eradicated in nine of 10 duodenal ulcer patients.
ACID RESPONSE TO GASTRIN RELEASING PEPTIDE At gastrin releasing peptide $40 \mathrm{pmol} / \mathrm{kg} / \mathrm{h}$ the median acid output ( $\mathrm{mmol} / \mathrm{h}$ ) in the $H$ pylori positive healthy volunteers $(15 \cdot 1$, range 3.3-38.3) was about three times that of the $H$ pylori negative healthy volunteers $(5 \cdot 5$, range 

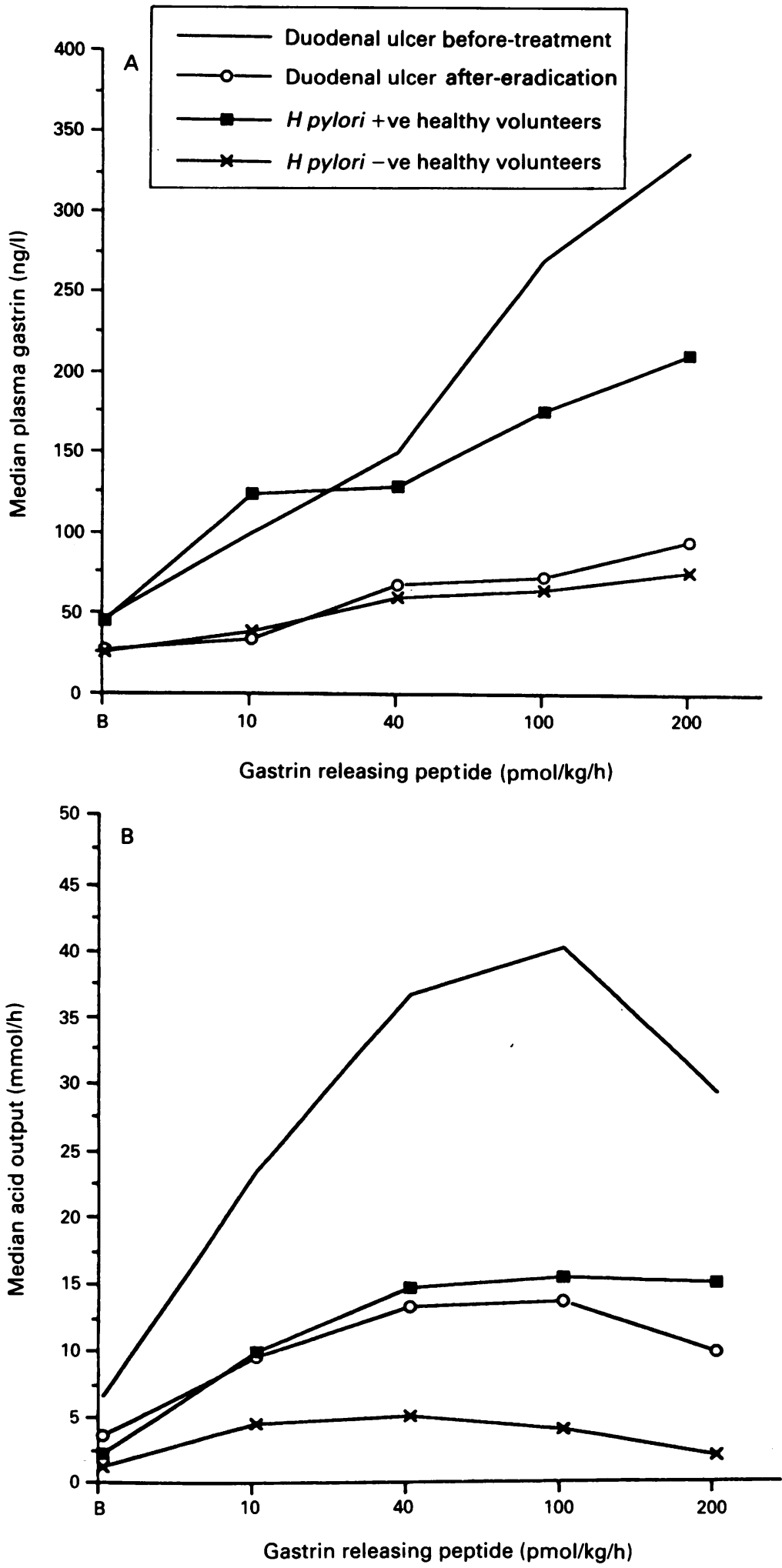

Figure 3: Median plasma gastrin concentration $(A)$ and median acid output $(B)$ in response to increasing infusion rates of gastrin releasing peptide in the different groups examined.

$1 \cdot 0-9 \cdot 0)(\mathrm{p}<0 \cdot 02)($ Fig 2B). At this infusion rate the median acid output in the $H$ pylori positive duodenal ulcer patients was 37 (range 8.5-57), which was about twice that of the $H$ pylori positive healthy volunteers $(\mathrm{p}<0.02)$ and six times that of the $H$ pylori negative healthy volunteers $(p<0.001)$. After eradication of $H$ pylori the acid output in the nine duodenal ulcer patients fell by a median of $66 \%$ (range $30 \%-80 \%$ ) to a median value of $13.7 \mathrm{mmol} / \mathrm{h}$ (range 6.2-24) $(\mathrm{p}<0.01)$ and thus became similar to that of the $H$ pylori positive healthy volunteers but remained higher than the $H$ pylori negative healthy volunteers $(p<0.005)$. Gastrin mediated acid secretion did not fall in the one patient whose infection was not eradicated (Fig 2B).

The acid response to gastrin releasing peptide was again consistent in the four groups at each of the infusion rates of gastrin releasing peptide studied (Fig 3B).

PEPSIN RESPONSE TO GASTRIN RELEASING PEPTIDE The pepsin response to gastrin releasing peptide showed the same pattern as the acid response at each infusion rate of gastrin releasing peptide. The differences between the groups, however, were most evident at the gastrin releasing peptide infusion rate of $100 \mathrm{pmol} / \mathrm{kg} / \mathrm{h}$ (Fig 4).

In response to gastrin releasing peptide 100 $\mathrm{pmol} / \mathrm{kg} / \mathrm{h}$ the median pepsin output (units $/ \mathrm{h}$ ) in the $H$ pylori positive healthy volunteers (18, 15-43) was higher than the $H$ pylori negative volunteers $(12,6-25)(p<0.02)$. The median pepsin output in the $H$ pylori positive duodenal ulcer patients $(29,19-60)$ was higher than both the $H$ pylori positive $(\mathrm{p}<0.005)$ and negative $(\mathrm{p}<0.001)$ healthy volunteers. Eradication of $H$ pylori in the duodenal ulcer patients lowered their pepsin output by a median of $55 \%$ to 17 units/h $(11-55)(\mathrm{p}<0.03)$ making them similar to the $H$ pylori positive healthy volunteers.

\section{Discussion}

This study shows that chronic $H$ pylori infection is accompanied by appreciably increased gastric acid output in both healthy volunteers and duodenal ulcer patients. It also shows that the infection increases both basal and stimulated acid secretion.

In the healthy volunteers with $H$ pylori both their basal gastrin and gastrin response to gastrin releasing peptide were increased compared with the $H$ pylori negative healthy volunteers. The two-threefold increase in gastrin response to gastrin releasing peptide in the $H$ pylori positive healthy volunteers is consistent with their previously reported two-threefold increased gastrin response to a meal. ${ }^{69}$ The design of this study allowed us to show that this increased gastrin response is accompanied by a concomitant threefold increase in acid secretion. This is consistent with the recent studies showing that the increased gastrin concentration in $H$ pylori infection is due to a rise in the biologically active G17 form of the hormone. ${ }^{1516}$

The duodenal ulcer patients with $H$ pylori infection resembled the $H$ pylori positive healthy volunteers with respect to their serum gastrin concentrations both basally and at each infusion rate of gastrin releasing peptide. This is consistent with our previous finding that the gastrin response to a meal is exaggerated by a similar extent in $H$ pylori positive duodenal ulcer patients and $H$ pylori positive healthy volunteers. ${ }^{6}$ The $H$ pylori positive duodenal ulcer patients and $H$ pylori positive healthy volunteers differed, however, with respect to gastrin mediated acid secretion, which was increased sixfold 


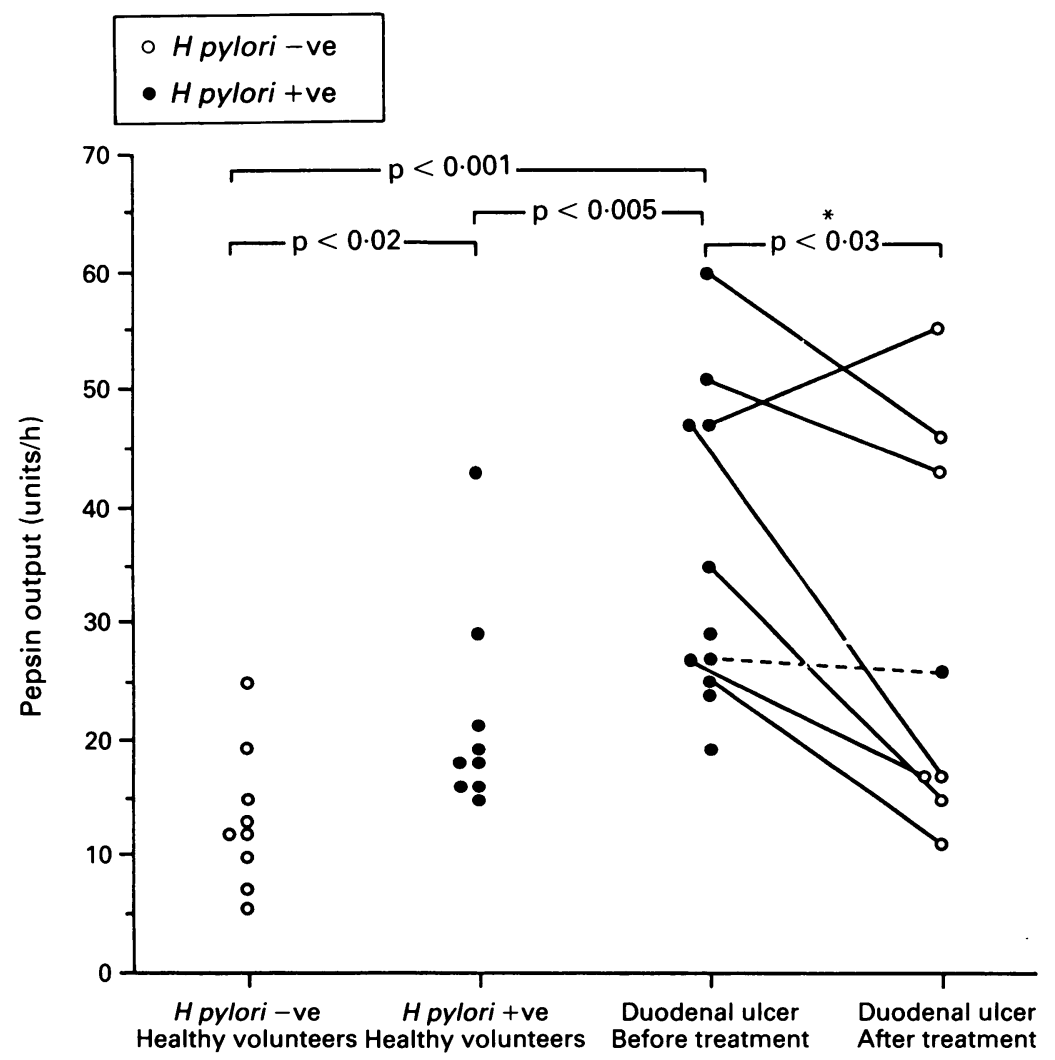

Figure 4: Pepsin output during intravenous infusion of gastrin releasing peptide (100 pmol/ $\mathrm{kg} / \mathrm{h}$ ) in healthy volunteers with and without $\mathrm{H}$ pylori and in duodenal ulcer patients before and after $\mathrm{H}$ pylori eradication treatment. The before and after treatment values in the patient in whom the infection was not eradicated are joined by broken line. ${ }^{\star}$ Statistics applies only to the patients in whom the infection was eradicated.

in the first but only threefold in the second when compared with $H$ pylori negative healthy volunteers. The fact that the duodenal ulcer patients secreted more than twice as much acid as the $H$ pylori positive healthy volunteers despite having equivalent gastrin concentrations shows that the duodenal ulcer patients have an exaggerated acid response to stimulation by gastrin. This finding is consistent with the previous studies showing that duodenal ulcer patients have an increased sensitivity to pentagastrin ${ }^{17-19}$ as well as to endogenous gastrin released in response to a peptone meal. ${ }^{20}$

Our data, therefore, show that subjects with $H$ pylori infection who develop duodenal ulceration have two disturbances of gastric function: (1) increased release of gastrin by the antral mucosa and (2) an exaggerated acid response to stimulation by gastrin. It is this dual defect that causes their considerable sixfold increase in gastrin mediated acid secretion. The increased antral gastrin release is explained by the $H$ pylori infection though the mechanism by which the infection stimulates gastrin release is unknown. It may be secondary to the recent findings of reduced somatostatin concentrations in the presence of $H$ pylori infection. ${ }^{21}{ }^{22}$ The exaggerated acid response to gastrin can be explained by the increased parietal cell mass present in duodenal ulcer patients. ${ }^{23}$ The increased parietal cell mass may be due to the longterm trophic effects of $H$ pylori induced hypergastrinaemia on the oxyntic mucosa, ${ }^{24}{ }^{25}$ due to smoking, ${ }^{26}$ represent the genetic factor in duodenal ulcer, or be due to any combination of these.
After eradication of $H$ pylori infection in the duodenal ulcer patients their gastrin fell to the same value as the $H$ pylori negative healthy volunteers and this was accompanied by a $66 \%$ fall in their gastrin mediated acid secretion after gastrin releasing peptide. This brought acid secretion in the duodenal ulcer patients into the range of the $H$ pylori positive healthy volunteers but it did not fall to the values of $H$ pylori negative healthy volunteers. This is explained by the fact that eradicating $H$ pylori resolved the increased acid secretion caused by the increased antral gastrin release but did not resolve that caused by their exaggerated acid response to gastrin. The second finding is consistent with our previous study showing that the response to pentagastrin stimulation in duodenal ulcer patients is not changed after eradication of $H$ pylori. ${ }^{27}$ The fact that the exaggerated acid response to gastrin did not resolve after eradication of $H$ pylori does not exclude it being due to trophic effects of $H$ pylori induced hypergastrinaemia on the oxyntic mucosa. The half life of the parietal cell is 23 days in rats ${ }^{28}$ and presumably much longer in man and therefore it could take many months for resolution of an increased parietal cell mass.

Increased basal and nocturnal acid output are also important features of duodenal ulcer disease $\mathrm{e}^{29}$ and in this study the median basal acid output of the $H$ pylori positive duodenal ulcer patients was five times that of the $H$ pylori negative healthy volunteers. After eradication of $H$ pylori in the duodenal ulcer patients both their basal acid output and basal gastrin fell by $50 \%$. Though gastrin is considered to be the main mediator of food stimulated acid secretion, ${ }^{10}$ its role in the regulation of basal acid output is unclear. The fact that the fall in basal gastrin with eradication of $H$ pylor $i$ in the duodenal ulcer patients was accompanied by a fall in basal acid secretion suggests that the increased basal gastrin was stimulating gastric secretion in the absence of food. Further evidence of this is the fact that the value of gastrin that increased acid secretion after gastrin releasing peptide in the $H$ pylori negative healthy volunteers was equivalent to the basal gastrin value in the $H$ pylori positive duodenal ulcer patients. Though basal gastrin was increased to a similar extent in $H$ pylori positive healthy volunteers and $H$ pylori positive duodenal ulcer patients the first did not have a significantly increased basal acid output. This may be explained by the fact that the increased basal acid output in duodenal ulcer patients was due to their combination of increased basal gastrin and exaggerated acid response to gastrin. It is probable that the increased basal gastrin is also stimulating increased basal acid secretion in the $H$ pylori positive healthy volunteers, which will become discernible after lowering of the gastrin by eradicating the infection.

In addition to increased acid secretion, duodenal ulcer patients are known to have increased pepsin secretion ${ }^{31}$ and it is the increased exposure to this combination of acid and pepsin that is likely to be injurious to the duodenal mucosa. In our studies pepsin output correlated closely with acid output. The beneficial effect of eradicating $H$ pylori in duodenal ulcer patients is therefore 
explained by the consequent lowering of gastric acid and pepsin secretion to the values present in non-ulcer ( $H$ pylori positive) subjects.

The finding in this study that gastrin mediated acid secretion is so appreciably increased (sixfold) in duodenal ulcer patients compared with true normal subjects ( $H$ pylori negative healthy volunteers) implies that it is likely to be the key factor in the pathophysiology of duodenal ulcer disease. The effect of $H$ pylori on gastrin mediated acid secretion provides a scientific explanation for the role of the infection in the pathogenesis of duodenal ulceration.

Because of the fact that permanent reduction of acid secretion can be achieved by a single course of $H$ pylori eradication treatment, there seems little justification to continue to treat duodenal ulcer patients with repeated courses of expensive acid suppressive agents.

This work was supported by grants from the Biomedical Research Committee of the Scottish Home and Health Department and the Research Support Group of the Greater Glasgow Health Board. The authors gratefully acknowledge the assistance of the staff of the Department of Nuclear Medicine, Western Infirmary; the statistical advice of Miss Catherine Howie; the technical assistance of Mrs Devina Fillmore, Sister Liz Spence, and Mrs Jennifer
Harwood and the invaluable secretarial assistance of Mrs Dorothy Ronney.

This work was presented at the 1992 Autumn Meeting of the British Society of Gastroenterology and appeared as an abstract in Gut.

1 Marshall BJ, Goodwin CS, Warren JR, Murray R, Blincow ED, Blackburn SJ, et al. Prospective double-blind trial of duodenal ulcer relapse after eradic

2 Coghlan JG, Gilligan D, Humphries H, McKenna D, Dooley C, Sweeney E, et al. Campylobacter pylori and recurrence of duodenal ulcers - a 12 month follow-up study. Lancet 1987; ii: $1109-11$.

3 Rauws EAJ, Tytgat GNJ. Cure of duodenal ulcer associated with eradication of Helicobacter pylori. Lancet 1990; 335: 1233-5.

4 Fiocca R, Solcia E, Santoro B. Duodenal ulcer relapse after eradication of Helicobacter pylori. Lancet 1991; i: 337, 1614.

5 McColl KEL, Fullarton GM, Chittajallu R, El Nujumi AM, Macdonald AMI, Dahill SW, et al. Plasma gastrin, daytime intragastric $\mathrm{pH}$, and nocturnal acid output before and at 1 intragastric $\mathrm{pH}$, and nocturnal acid output before and at 1 and 7 months after eradication of Helicobacter pylori in duodenal

6 Chittajallu RS, Ardill JES, McColl KEL. The degree of hypergastrinaemia induced by Helicobacter pylori is the same in duodenal ulcer patients and asymptomatic volunteers. Eur f Gastroenterol Hepatol 1992; 4: 49-53.

7 Levi S, Bearsdshall K, Swift I, Foulkes W, Playford R, Ghosh $\mathrm{P}$, et al. Antral Helicobacter pylori, hypergastrinaemia and
duodenal ulcer: effect of eradicating the organism. $B M \mathcal{F}$ 1989; 299: 1504-5.

8 Graham DY, Opekum A, Lew GM, Evans DJ, Klein PD, Evans DG. Ablation of exaggerated meal-stimulated gastrin release in duodenal ulcer patients after clearance of Helicobacter (Campylobacter) pylori infection. $A m \mathcal{F}$ Gastroenterol 1990; 85 4: 394-8.

9 Prewett EJ, Smith JTL, Nwokolo CU, Hudson M, Sawyer AM, Pounder RE. Eradication of Helicobacter pylor bolishes 24-hour hypergastrinaemia: a prospective study in healthy subjects. Aliment Pharmacol Therap 1991; 5: 283-90.

10 Kovacs TOG, Walsh JH, Maxwell V, Wong HC, Azuma T, Katt E. Gastrin is a major mediator of the gastric phase of acid secretion in dogs: proof by monoclonal antibody neutralization. Gastroenterology 1989; 97: 1406-13.

11 Ghatei MA, Jung RT, Stevenson JC, Hillyard CJ, Adrian TE Lee YC, et al. Bombesin: action on gut hormones and calcium in man. $\mathcal{F}$ Clin Endocrinol Metab 1982; 54: 980-5.

12 Guo Y-S, Thompson JC, Singh P. Role of gastrin in bombesinstimulated

13 Gray SP, Billings JA. Kinetic assay of human pepsin with albumin-bromophenol blue as substrate. Clin Chem 1983; 29: 447-51.

14 Ardill JES. Radioimmunoassay of GI hormones. Clin Endocrinol Metab 1979; 8: 265-80.

15 Beardshall K, Moss S, Gill J, Levi S, Ghosh P, Playford RJ et al. Suppression of Helicobacter pylori reduces gastrin releasing peptide stimulated gastrin release in duodena ulcer patients. Gut 1992; 33: 601-3.

16 Mulholland G, Ardill JES, Fillmore D, Chittajallu RS Fullarton GM, McColl KEL. Helicobacter pylori related hypergastrinaemia is the result of a selective increase in gastrin 17. Gut 1993; 34: 757-61.

17 Johnson D, Jepson $\mathrm{K}$. Use of pentagastrin in a test of gastric acid secretion. Lancet 1967; ii: 585 .

18 Petersen H, Myren J. Pentagastrin-dose response in peptic ulcer disease. Scand f Gastroentrol 1975; 10: 705-14.

19 Isenberg JI, Grossman MI, Maxwell V, Walsh JH. Increased sensitivity to stimulation of acid secretion by pentagastrin in sensitivity to stimulation of acid secretion by

20 Lam SK, Isenberg JI, Grossman MI, Lane WH, Walsh JH. Gastric acid secretion is abnormally sensitive to endogenous gastrin released after peptone test meals in duodenal ulce patients. F Clin Invest 1980; 65: 555-62.

21 Kaneko H, Nakada K, Mitsuma T, Uchida K, Furusawa A, Maeda Y, et al. Helicobacter pylori infection induces decrease in immunoreactive-somatostatin concentrations of human stomach. Dig Dis Sci 1992; 37: 409-16.

22 Moss SF, Legon S, Bishop HE, Polak JM, Calam J. Effect of Helicobacter pylori on gastric somatostatin in duodenal ulcer disease. Lancet 1992; 340: 930-3.

23 Cox AJ. Stomach size and its relation to chronic peptic ulcer. Arch Pathol 1952; 54: 407

24 Willems G, Lehy T. Radioautographic and quantitative studies on parietal and peptic cell kinetics in the mouse. A selective effect of gastrin on parietal cell proliferation. Gastroenterology 1975; 69: 416-26.

25 Crean GP, Marshall MW, Ramsey RDE. Parietal cell hyperplasia induced by the administration of pentagastrin (ICI $50,123)$ to rats. Gastroenterology $1969 ; 57: 147-55$.

26 Lanas A, Hirschowitz BI. Influence of smoking on basal and on vagally and maximally stimulated gastric acid secretion and pepsin secretion. Scand $\mathcal{f}$ Gastroenterol 1992; 27: 208-13.

27 Chittajallu RS, Howie CA, McColl KEL. Effect of Helicobacter pylori on parietal cell sensitivity to pentagastrin in bacter pylori on parietal cell sensitivity to pentagastrin in $857-62$.

28 Ragins H, Wincze F, Liu SM, Dittbrenner M. The origin and survival of gastric parietal cells in the mouse. Anat Rec 1968; 162: $99-110$.

29 Dragstedt LR. Gastric secretion tests. Gastroenterology 1967; 52: 587

30 Feldman M, Richardson CT. Total 24-hour gastric acid secretion in patients with duodenal ulcer. Gastroenterology 1986; 90: 540

31 Walker V, Taylor WH. Pepsin I secretion in chronic peptic ulceration. Gut 1980; 21 : 766-71. 